\title{
Evaluation of NF2 and NF1 Tumor Suppressor Genes in Distinctive Gastrointestinal Nerve Sheath Tumors Traditionally Diagnosed as Benign Schwannomas: A Study of 20 Cases
}

\author{
Jerzy Lasota, Bartek Wasąg, Agnieszka Dansonka-Mieszkowska, Danuta Karcz, \\ Carl L. Millward, Janusz Ryś, Jerzy Stachura, Leslie H. Sobin, and \\ Markku Miettinen
}

Department of Soft Tissue Pathology (JL, BW, AD-M, CLM, MM) and Department of Hepatic and Gastrointestinal Pathology (LHS), Armed Forces Institute of Pathology, Washington, DC; and Second Department of Surgery (DK) and Department of Pathology (JS), Jagiellonian University, and Department of Pathology (JR), Maria Skłodowska-Curie Memorial Institute, Kraków, and Department of Biology and Genetics (BW), Medical University of Gdansk, Gdansk, and Department of Molecular Pathology (AD-M), Maria Skłodowska-Curie Memorial Institute, Warsaw, Poland

SUMMARY: A significant percentage of conventional schwannomas, whether sporadic or associated with neurofibromatosis 2 (NF2), show loss of heterozygosity (LOH) at NF2 and/or NF2 inactivating mutations. Similarly, a significant percentage of neurofibromas show LOH at NF1 and/or NF1 inactivating mutations. There are no molecular genetic data on gastrointestinal (Gl) nerve sheath tumors traditionally diagnosed as benign schwannomas, rare neoplasms possibly derived from the schwannian elements dispersed between the smooth muscle fibers. In this study, we analyzed 1 esophageal, 16 gastric, 1 small intestinal, and 2 colonic tumors of such type. Histologically, all were spindle cell neoplasms positive for S-100 protein, vimentin, and glial fibrillary acidic protein, and negative for smooth muscle markers, KIT, CD34, neurofilament proteins, and HMB45. Focal or extensive lymphoid cuffs, often containing germinal centers, were present in most cases. None of the patients had NF2 or NF1. Chromosomes 22 and 17, particularly NF2 and NF1 loci, were analyzed for LOH in all Gl tumors and for comparative purposes in 10 conventional schwannomas. $\mathrm{LOH}$ on $22 \mathrm{q}$ was seen in $40 \%$ of conventional schwannomas but in only $5 \%$ (1 of 20 ) of Gl schwannomas. PCR amplification followed by direct sequencing of PCR products failed to identify mutations in NF2 coding sequences (exons 1-15) in 13 cases, including a case with LOH on 22q. Losses on 17q involving NF1 were seen in both Gl and conventional schwannomas in $50 \%$ and $33 \%$ of analyzed tumors, respectively. LOH at NF1 might be one of the genetic features seen in peripheral nerve sheath tumors from different locations and should be interpreted with caution. However, lack of NF2 alterations strongly supports the hypothesis that GI schwannomas represent a morphologically and genetically distinct group of peripheral nerve sheath tumors that are different from conventional schwannomas. (Lab Invest 2003, 83:1361-1371).

$D$ istinctive benign nerve sheath tumors traditionally diagnosed as schwannomas have been documented in the gastrointestinal (Gl) tract. Their most common location is the stomach, followed by the colon and the rectum. Occasionally, similar tumors

DOI: 10.1097/01.LAB.0000087591.29639.E3

Received July 7, 2003.

This study was supported by a grant from the Polish Committee for Scientific Research (3 P05C 059 25) and the American Registry of Pathology. The opinions and assertions contained herein are the expressed views of the authors and are not to be construed as official or reflecting the views of the Departments of the Army or Defense. B. Wasag and A. Dansonka-Mieszkowska are Research Fellows at the Department of Soft Tissue Pathology, Armed Forces Institute of Pathology, Washington, DC (B.W. 2000-2001).

Address reprint requests to: Dr. J. Lasota, Department of Soft Tissue Pathology, Armed Forces Institute of Pathology, 14th Street and Alaska Avenue, N.W., Washington, DC 20306-6000. E-mail: lasota@afip.osd.mil have been reported in the small intestine and esophagus. Gl schwannomas are cellular spindle cell tumors with a microtrabecular pattern and lack of nuclear palisading. Peripheral lymphoid foci, sometimes with germinal center formation, are a common histologic feature. The tumor cells are positive for S-100 protein and glial fibrillary acidic protein (GFAP) and negative for desmin and $\alpha$-smooth muscle actin (SMA), unlike true leiomyomas, and negative for KIT (CD117) and CD34, unlike Gl stromal tumors. All tumors with such phenotypic features reported thus far have followed a benign clinical course (Daimaru et al, 1988; Hirose et al, 1997; Miettinen et al, 2001; Prévot et al, 1999; Sarlomo-Rikala and Miettinen, 1995; Sasatomi et al, 2000; Skopelitou et al, 1998; Tomozawa et al, 1998; Yagihashi et al, 1997).

Neurofibromatosis 2 (NF2) is an autosomal dominant disorder caused by genetic alterations of the NF2 tumor suppressor gene (Gutmann, 1997). NF2 is 
mapped to 22q12 and encodes for a protein designated as merlin or schwannomin (Hovens and Kaye, 2001; Rouleau et al, 1993; Trofatter et al, 1993). Bilateral vestibular schwannomas are a typical diagnostic feature of NF2. In these tumors, both NF2 alleles are inactivated by deletion or mutation, according to the two-hit hypothesis of inactivation of a recessive tumor suppressor gene (Knudson, 1971).

Monosomy of chromosome 22 and alterations of NF2 have been shown to be the most common genetic aberration in sporadic, conventional schwannomas and to play a central role in their tumorigenesis (Heim and Mitelman, 1995). Protein studies have revealed reduced expression or absence of the NF2 product, merlin, in a majority of conventional schwannomas (Gutmann et al, 1997; Stemmer-Rachamimov et al, 1997; Twist et al, 1994).

Neurofibromatosis type 1 is an autosomal dominant disorder caused by genetic alterations of the NF1 tumor suppressor gene (Cichowski and Jacks, 2001; Rasmussen and Friedman, 2000). NF1 is mapped to the pericentromeric region of chromosome 17 (17q11.2) and encodes for a protein called "neurofibromin" (Xu et al, 1990a). Loss of heterozygosity (LOH) at the NF1 locus and inactivating mutations in the NF1 gene have been shown in NF1-associated and sporadic malignancies including neurofibromas, plexiform neurofibromas, malignant peripheral nerve sheath tumors, pilocytic astrocytomas, and desmoplastic/neurotropic melanomas (Colman et al, 1995; Däschner et al, 1997; Eisenbarth et al, 2000; Gutzmer et al, 2000; John et al, 2000; Kluwe et al, 1999, 2001; Lothe et al, 1995; Perry et al, 2001; Rasmussen et al, 2000; Serra et al, 1997; Skuse et al, 1989).

Although the first report defining morphologic and immunohistochemical features of Gl schwannomas dates back to the 1980s (Daimaru et al, 1988), there are no genetic studies regarding these tumors. The purpose of this study was to analyze $20 \mathrm{Gl}$ schwannomas for alterations of NF2 and NF1 tumor suppressor genes. $\mathrm{LOH}$ at the NF2 locus and inactivating mutations in the NF2 gene would strongly suggest that Gl schwannomas share molecular genetic similarities with conventional schwannomas. On the contrary, lack of such changes would distinguish these tumors from conventional schwannomas.

\section{Results}

\section{Clinical Features}

The demographic and clinical data of the tumors analyzed in this study are summarized in Table 1. Of the 20 patients, 16 were women and 4 were men. The age of the patients ranged from 18 to 78 (median 56, mean 53) years. Sites of involvement were the esophagus $(n=1)$, stomach $(n=16)$, small bowel $(n=1)$, and colon $(n=2)$. None of the patients had NF1 or NF2.
Table 1. Summary of Demographic and Clinical Data of 20 GI Schwannomas Analyzed

\begin{tabular}{rlllr}
\hline Case & $\begin{array}{c}\text { Age } \\
(\mathrm{yr})\end{array}$ & Sex & \multicolumn{1}{c}{ Location } & $\begin{array}{r}\text { Size } \\
(\mathrm{mm})\end{array}$ \\
\hline 1 & 36 & $\mathrm{M}$ & Esophagus & 35 \\
2 & 72 & $\mathrm{~F}$ & Stomach & 25 \\
3 & 62 & $\mathrm{~F}$ & Stomach & 25 \\
4 & 47 & $\mathrm{~F}$ & Stomach & 30 \\
5 & 54 & $\mathrm{~F}$ & Stomach & 30 \\
6 & 56 & $\mathrm{~F}$ & Stomach & 30 \\
7 & 56 & $\mathrm{~F}$ & Stomach & 30 \\
8 & 72 & $\mathrm{~F}$ & Stomach & 35 \\
9 & 78 & $\mathrm{~F}$ & Stomach & 35 \\
10 & 24 & $\mathrm{~F}$ & Stomach & 38 \\
11 & 39 & $\mathrm{~F}$ & Stomach & 45 \\
12 & 48 & $\mathrm{M}$ & Stomach & 50 \\
13 & 63 & $\mathrm{M}$ & Stomach & 50 \\
14 & 66 & $\mathrm{~F}$ & Stomach & 60 \\
15 & 43 & $\mathrm{~F}$ & Stomach & 70 \\
16 & 55 & $\mathrm{~F}$ & Stomach & 70 \\
17 & 64 & $\mathrm{~F}$ & Stomach & 100 \\
18 & 30 & $\mathrm{M}$ & Small intestine & 35 \\
19 & 75 & $\mathrm{~F}$ & Colon & 40 \\
20 & 18 & $\mathrm{~F}$ & Colon & 50 \\
\hline & & & &
\end{tabular}

\section{Histologic and Immunohistochemical Features}

Histologically all GI schwannomas were moderately cellular spindle cell tumors, which were surrounded by a variably sized lymphoid cuff, often containing germinal centers. The tumor cells were often grouped in a trabecular fashion, separated by variably thick fibrovascular septa, and lacked the typical nuclear palisading and xanthoma cells commonly seen in conventional schwannomas. Focal nuclear atypia was noted in all tumors, but mitotic activity was low and did not exceed 5 mitoses per 50 high-powered field. Representative histologic images are shown in Figure 1.

All tumors were globally positive for vimentin and S100-protein, with both cytoplasmic and nuclear positivity for the latter. Extensive positivity GFAP was documented in 14 cases. All tumors were negative for KIT (CD117), neurofilament proteins, desmin, HMB45, and SMA and all but one for CD34. Representative immunohistochemical images are shown in Figure 2.

\section{NF2 and NF1 Status in GI Schwannomas}

A summary of the LOH studies on chromosomes 22 and 17 is shown in Figure 3. LOH study on chromosome 22 was performed using 13 polymorphic markers, of which 7 have been mapped to NF2. Eighteen of $20 \mathrm{Gl}$ schwannomas were informative for at least one intragenic NF2 marker. Two cases that were noninformative for intragenic NF2 markers were informative for the markers flanking the NF2 locus. LOH at NF2 was identified in only one tumor (Case 18). However, evaluation of this tumor for other markers flanking NF2 revealed $\mathrm{LOH}$, suggesting the presence of a large 

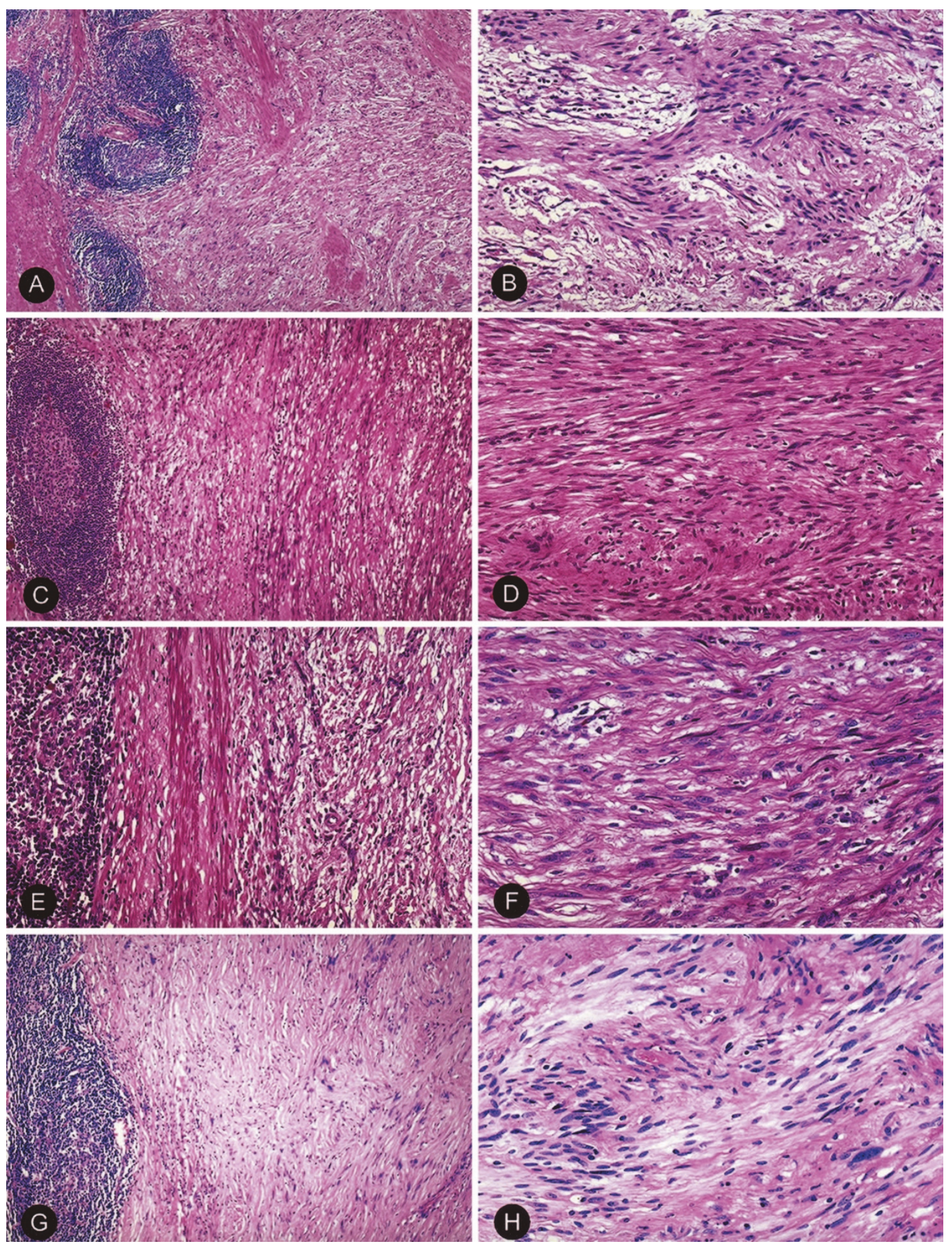

\section{Figure 1.}

Representative examples of gastrointestinal (GI) schwannomas reveal moderately cellular spindle cell tumors surrounded by extensive lymphoid cuff ( $\mathrm{A}$, $\mathrm{C}$, E, and $G)$. Higher magnifications show edematous perivascular spaces with lymphocytes, variable palisading $(B, D, F$, and $H)$, and focal nuclear atypia $(H)$. $A$ and $B, C a s e$ 2; $\mathrm{C}$ and D, Case 3; E and F, Case 7; G and H, Case 12.

interstitial deletion or loss of the entire 22q. In 13 cases, including a case with LOH on 22q, NF2 coding sequences (exons 1-15) were evaluated for the presence of mutations by PCR amplification and direct sequencing of PCR products. No mutations were found.

LOH study on chromosome 17 was performed using 11 polymorphic markers, of which 4 have been 

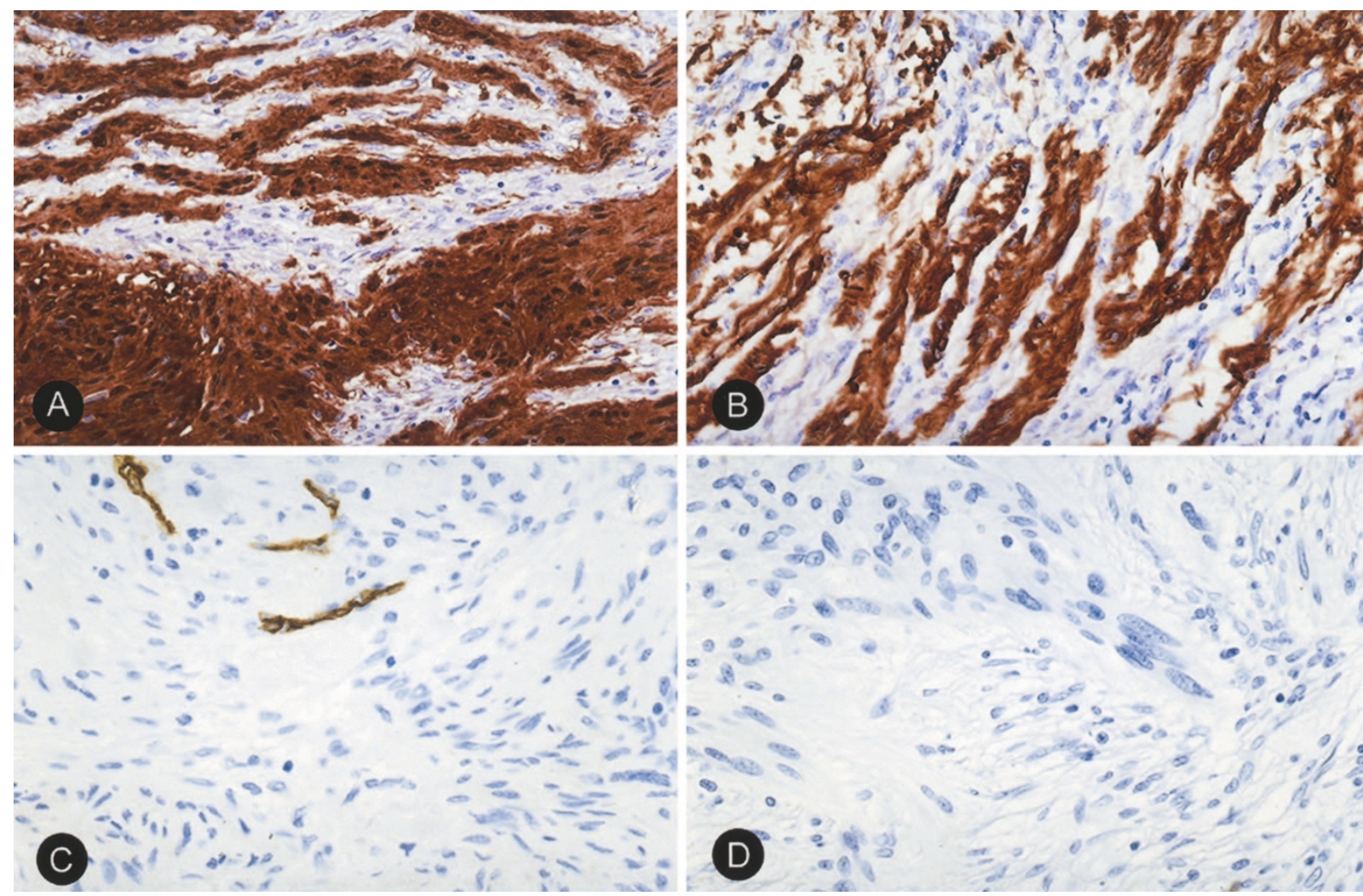

Figure 2.

Immunohistochemical features of Case 19, a colonic schwannoma. Positive immunostainings for S-100 (A) and glial fibrillary acidic protein (B) and negative immunostainings for CD34 (C) and neurofilament proteins (D).

mapped to NF1. Nineteen of 20 Gl schwannomas were informative for at least one of the NF1 intragenic markers. $\mathrm{LOH}$ on $17 \mathrm{q}$ was detected in $50 \%$ of analyzed cases. Losses of NF1 or intragenic NF1deletions were found in 9 of 10 tumors showing $\mathrm{LOH}$ on $17 \mathrm{q}$. In Case 16, partial loss of NF1 could not be excluded, because the only lost marker was mapped immediately centromeric to NF1 and the following NF1 intragenic markers were noninformative. The most frequently deleted NF1 region was defined by intron 1 and exon 5 markers. In Case 19, however, a unique loss of the region flanked by the intron 27 and intron 38 markers was identified. Representative examples of LOH studies on chromosome 17 in Gl schwannomas are shown in Figures 4 and 5.

\section{NF2 and NF1 Status in Conventional Schwannomas}

For comparative purposes, 10 conventional schwannomas were screened with the same set of polymorphic markers for LOH on chromosomes 22 and 17. As expected, based on previously published studies (Mertens et al, 2000; Mitelman, 1998), LOH on chromosome arm $22 \mathrm{q}$ was found in $40 \%$ of analyzed cases. In six cases, however, $\mathrm{LOH}$ on chromosome 17 was detected as well. Two tumors (20\%) showed LOH on the $p$ arm and 3 (33\%) on the $q$ arm; 1 tumor had lost all informative markers, suggesting monosomy of chromosome 17. In two cases, LOH was documented exclusively in NF1, suggesting the presence of intra- genic deletions. Representative examples of $\mathrm{LOH}$ studies on chromosome 17 in conventional schwannomas are shown in Figure 5.

\section{Discussion}

Gl schwannomas are rare peripheral nerve sheath tumors that show a distinctive set of histologic features that differ from conventional central nervous system and peripheral, soft tissue schwannomas. These distinctive features include a peripheral lymphoid cuff, common microtrabecular pattern, and lack of nuclear palisading and xanthoma cells (Daimaru et al, 1988; Hirose et al, 1997; Miettinen et al, 2001; Prévot et al, 1999; Sarlomo-Rikala and Miettinen, 1995; Sasatomi et al, 2000; Scheithauer et al, 1999; Skopelitou et al, 1998; Tomozawa et al, 1998; Yagihashi et al, 1997). In this study, we evaluated NF2 and NF1 alterations in 20 well-documented Gl schwannomas using archival formaldehyde-fixed, paraffinembedded (FFPE) material.

NF2 is mapped to chromosome 22q12. It encodes for an intracellular cytoskeleton-associated protein of 595 amino acids, designated as merlin or schwannomin (Rouleau et al, 1993; Trofatter et al, 1993). Inactivating mutations of NF2 have been observed in $34 \%$ to $66 \%$ of the screened NF2 patients (Merel et al, 1995; Ruttledge et al, 1996). A majority of the mutations are nonsense, frameshift, or spliced donor site mutations, all of which result in a nonfunctional, trun- 

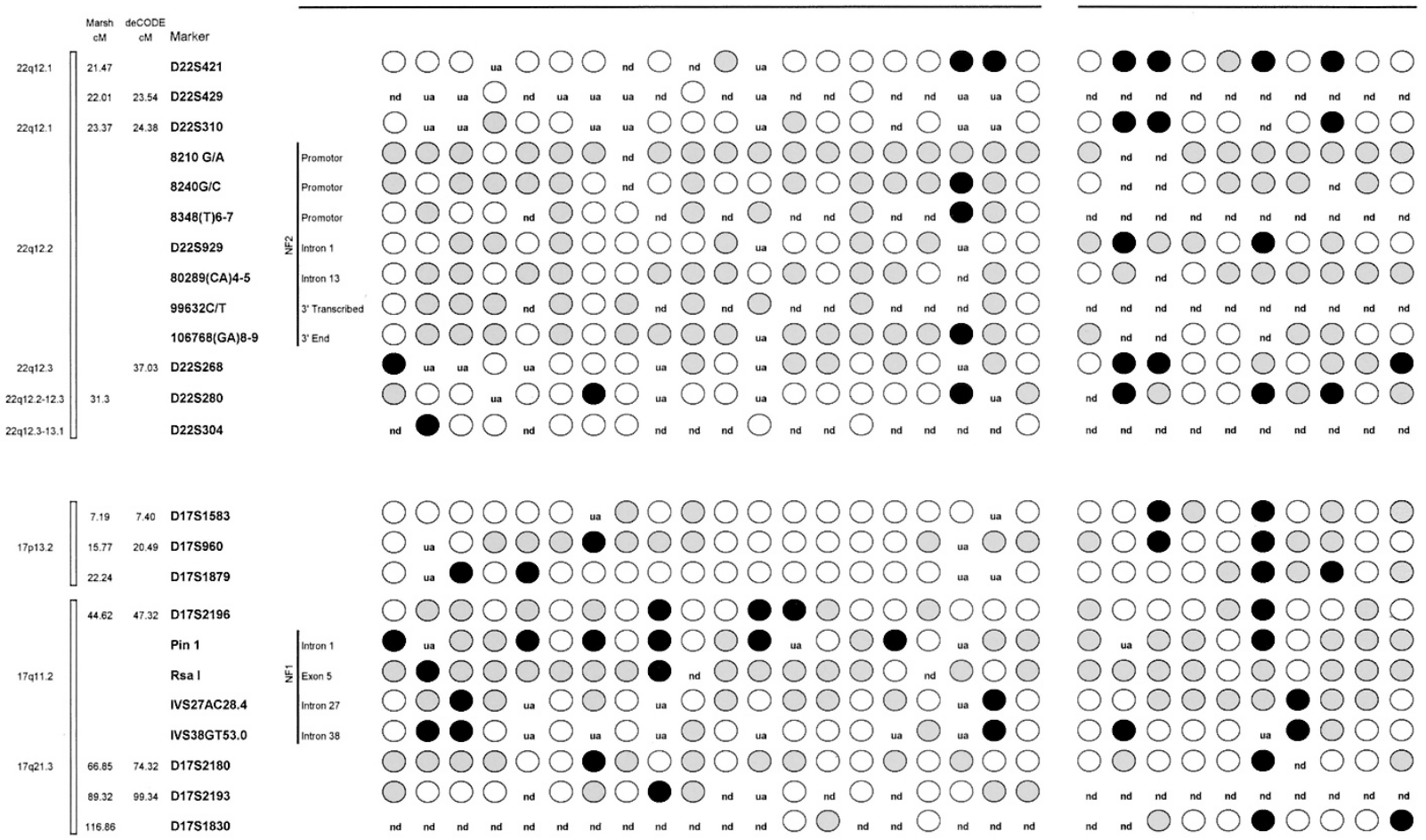

Figure 3.

Summary of loss of heterozygosity (LOH) studies on chromosomes 22 and 17 in GI and conventional schwannomas. Black circles indicate LOH, gray circles indicate noninformative markers, and white circles indicate heterozygosity (no LOH). Marker positions obtained from the genetic databases available online through NCBI (http://www.ncbi.nlm.nih.gov) are indicated. Marsh = Marshfield map; deCODE = deCODE map; $c M=$ centimorgan; ua = unsuccessful PCR amplification; $n d=$ not done.

cated protein. More recently, it was found that large deletions in the NF2 may be present in NF2 patients, raising the frequency of detectable NF2 alterations in this population to $84 \%$ (Zucman-Rossi et al, 1998). Development of bilateral vestibular schwannomas is a typical feature of NF2. In these tumors one allele of the NF2 is hereditarily mutated, whereas the other one is inactivated by somatic mutation.

Inactivating NF2 mutations, similar to those seen in NF2-associated tumors, have been found in $40 \%$ to $60 \%$ of sporadic conventional schwannomas (Bijlsma et al, 1994; Jacoby et al, 1996). The mutations are almost evenly distributed across NF2 exons 1-15 but do not occur in exons 16 and 17 of the gene (Jacoby et al, 1996). Protein studies have revealed reduced expression or absence of merlin in most sporadic conventional schwannomas (Gutmann et al, 1997; Stemmer-Rachamimov et al, 1997; Twist et al, 1994).

We evaluated NF2 in Gl schwannomas for $\mathrm{LOH}$ and for the presence of inactivating mutations. LOH at NF2 was rare, found in only 1 of 20 analyzed tumors. In that case, multiple markers were lost, suggesting loss of the entire $22 q$ or a large interstitial deletion, which may represent a random genetic event, unrelated to the NF2 inactivation. No NF2 inactivating mutations were found in any of the 13 analyzed tumors, including a case with $\mathrm{LOH}$ on $22 \mathrm{q}$. Thus, alteration of NF2 by a two-hit mechanism could not be verified in any of the analyzed Gl schwannomas, suggesting that the pathogenesis of these tumors differs from that of conventional schwannomas.

NF2 seems to be unaffected in up to $40 \%$ of conventional schwannomas (Bijlsma et al, 1994; Jacoby et al, 1996). Recently, several interstitial deletions in 22q, outside of the NF2 locus, were identified in a group of conventional schwannomas and were suggested to be involved in tumorigenesis (Bruder et al, 1999). Also, increased proteolytic degradation of merlin by calpain was shown in schwannomas without detected NF2 mutations (Kimura et al, 1998). This alternative mechanism of merlin inactivation should be explored in Gl schwannomas. Unfortunately, immunohistochemical evaluation for merlin is currently hampered by the lack of anti-merlin antibodies reactive in FFPE tissues.

The neurofibromatosis 1 gene is located at $17 q 11.2$ and encodes for a protein designated neurofibromin (Cawthon et al, 1990; Wallace et al, 1990). The function of neurofibromin is not fully understood (Cichowski and Jacks, 2001); however, there is strong evidence that neurofibromin, which shows high homology to the GTPase-activating proteins, is involved in the Ras pathway and negatively regulates the Ras product p21ras (McCormick, 1995; Wallace et al, 1990; Xu et al, 1990b; Yunoue et al, 2003). NF1 has been considered a recessive tumor suppressor gene in the sense that only inactivation of both NF1 alleles would lead to tumorigenesis as defined by Knudson's 

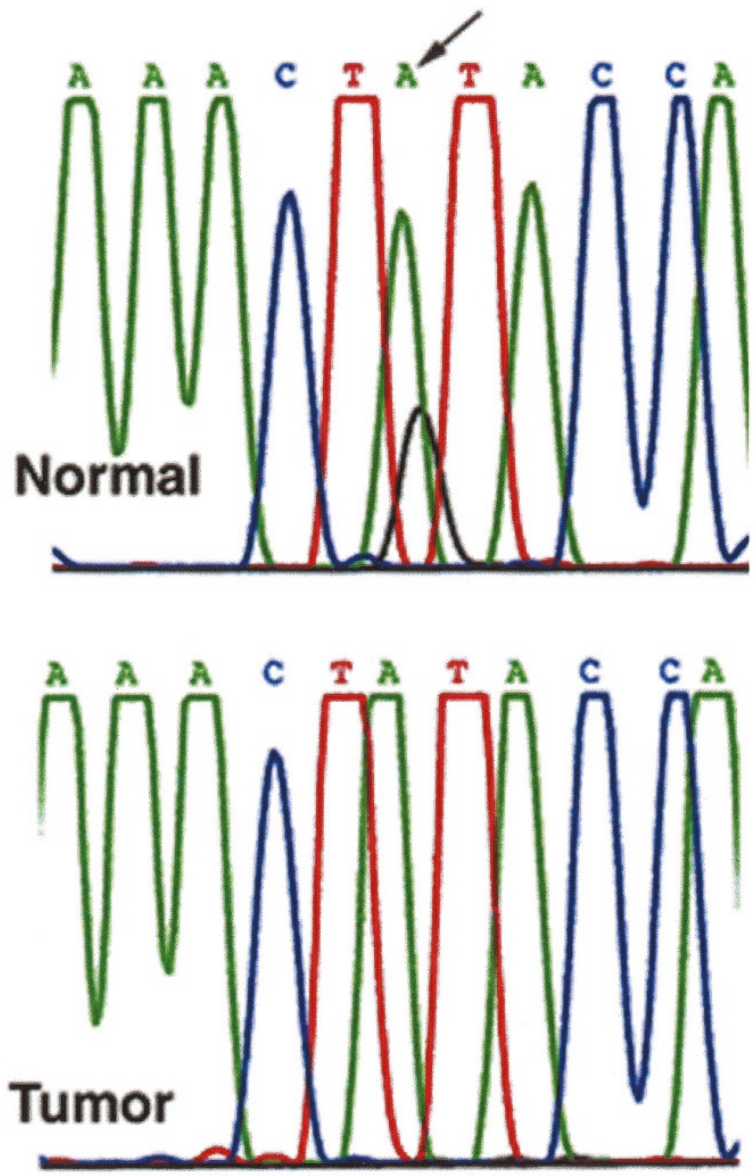

Figure 4.

Case 2: LOH of the NF1 exon 5 Rsal polymorphic marker documented by PCR amplification and direct sequencing. Arrow indicates polymorphic alleles in normal tissues.

two-hit hypothesis (Knudson, 1971). However, in vitro study on Schwann cells from NFs showed two genetically distinctive Schwann cell subpopulations within one tumor cell culture, with either one or two mutated alleles (Serra et al, 2000). A more recent study suggested that NF1-mediated neurofibroma formation requires loss of both NF1 alleles in Schwann cells, destined to become neoplastic, and the presence of NF1 heterozygosity in non-neoplastic cells of the local microenvironment (Zhu et al, 2002).

We evaluated 20 Gl schwannomas for $\mathrm{LOH}$ on chromosome 17 and detected losses involving NF1 in almost $50 \%$ of analyzed cases. This rate of $\mathrm{LOH}$ at the NF1 is similar to the one calculated for plexiform neurofibromas (Perry et al, 2001) based on previously reported data (Däschner et al, 1997; Kluwe et al, 1999; Rasmussen et al, 2000). The size of deletions in Gl schwannomas varies from large ones, probably involving the whole gene or the $17 \mathrm{q}$ arm, to relatively small ones, defined by a loss of one or two markers. The most frequently deleted NF1 region was defined by intron 1 and exon 5 markers. This region includes exon $4 \mathrm{~b}$, which has been considered to be one of the NF1 mutational "hot spots" in NF1 patients (Toliat et al, 2000). In one case, a unique loss of the region flanked by intron 27 and intron 38 markers was identified. This region was shown to be frequently deleted in sporadic and NF1-associated peripheral nerve sheath tumors and desmoplastic neurotropic melanomas (Gutzmer et al, 2000; Serra et al, 1997). Recent identification of the mutational hot spot in exon 37 strongly supports the hypothesis that specific sequences, which may encode functional domain, are in this region. Therefore, its mutational inactivation may play an important role in tumorigenesis (Boddrich et al, 1997; Messiaen et al, 1997; Robinson et al, 1995; Upadhyaya et al, 1996).

We did not evaluate NF1 in GI schwannomas for the presence of somatic mutations. Mutation analysis of NF1 is difficult because of the large size of the gene, which spans more than 350 kilobases of genomic DNA and contains 60 exons ( $\mathrm{Li}$ et al, 1995). Furthermore, the presence of several pseudogenes makes the PCR analysis of genomic DNA (especially partially degraded DNA extracted from FFPE tissues) difficult because of the coamplification of loci homologous to NF1. Molecular genetic studies based on fresh/frozen tissues are necessary to evaluate the possible inactivation of the second NF1 allele by somatic mutations as a critical step in the development of $\mathrm{Gl}$ schwannomas.

Conventional schwannomas, regardless of central nervous system or soft tissue location, were shown to have similar cytogenetic profiles, with loss of one copy of chromosome 22 as the most frequent alteration (Mertens et al, 2000). However, a few other cytogenetic changes, including monosomy of chromosome 17 , were reported in a small number of cases (Mitelman, 1998). More recently, a comparative genomic hybridization study reported losses on $17 \mathrm{p}$ and $17 \mathrm{q}$ in approximately $20 \%$ to $30 \%$ of soft tissue conventional schwannomas (Koga et al, 2002). Our findings indicate, however, that some of the losses on $17 q$ may specifically involve the NF1 locus. Further molecular genetic studies based on larger material are needed to evaluate whether mutational inactivation of NF1 plays a primary role in pathology of conventional schwannomas.

In summary, this study has documented lack of NF2 alterations and frequent $\mathrm{LOH}$ on chromosome $17 \mathrm{q}$ involving the NF1 locus in tumors traditionally diagnosed as Gl schwannomas. These data indicate that Gl schwannoma represents not only morphologically but also genetically distinctive group of peripheral nerve sheath tumors different from conventional schwannomas.

\section{Materials and Methods}

\section{Tissue Material}

Twenty GI schwannomas were obtained from the files of the Armed Forces Institute of Pathology (AFIP), Washington, DC; Jagiellonian University, Kraków, Poland; and Maria Skłodowska-Curie Memorial Institute, Kraków, Poland. A control group of 10 conventional schwannomas was selected from the collection of soft tissue schwannomas diagnosed at the Department of Soft Tissue Pathology, AFIP. 

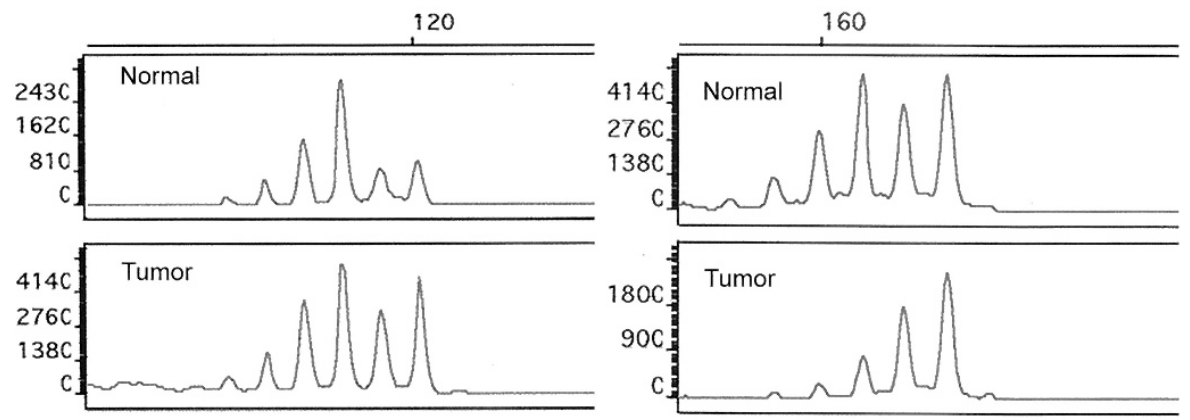

Case 26, D17S1583, $\mathrm{LOH}$ value $=0.4$

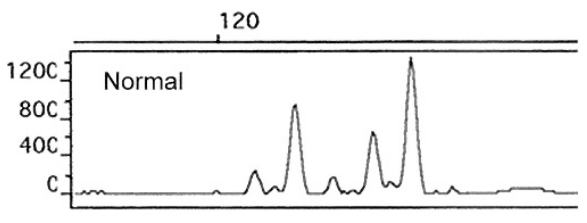

Case 28, D17S1879, $\mathrm{LOH}$ value $=0.3$
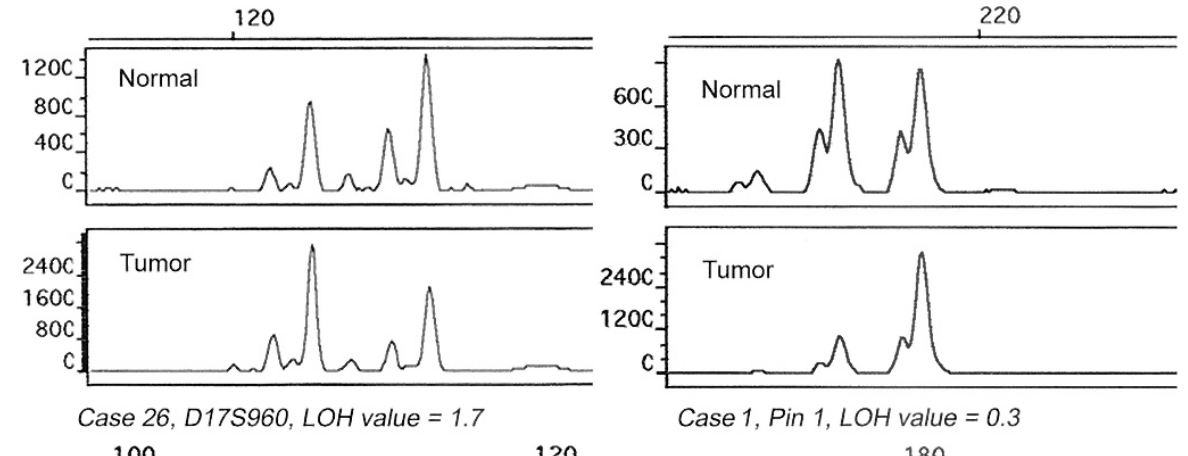

Case 1, Pin 1, $\mathrm{LOH}$ value $=0.3$
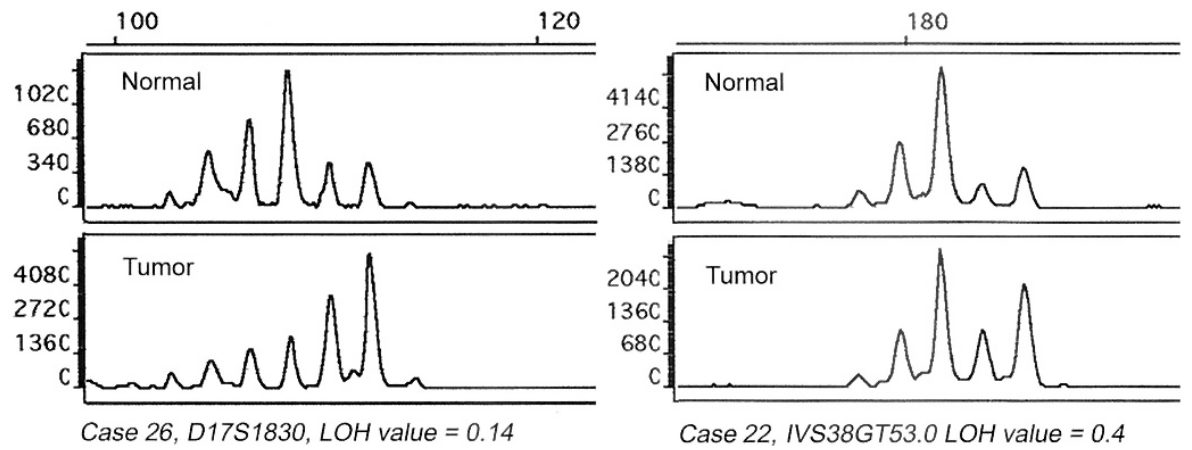

Figure 5.

Examples of LOH on chromosome 17 identified in $\mathrm{Gl}$ and conventional schwannomas by PCR amplification of microsatellite markers and capillary gel electrophoresis.

\section{Immunohistochemistry}

The tumors were immunohistochemically evaluated with a panel of antibodies to vimentin, S100 protein, GFAP, neurofilament proteins, SMA, desmin, HMB45, CD34, and CD117 using the ABC-immunoperoxidase technique as previously described (Miettinen et al, 2001).

\section{DNA Extraction}

In all cases, FFPE tissue samples of tumor and normal tissue were microdissected with razor blades. In Case 8, tumor cell population was enriched before DNA extraction. Standard histologic slides, stained with hematoxylin and eosin, were used for the laser capture microdissection (PixCell Laser Capture Microdissection System; Arcturus Engineering, Inc., Mountain View, California). The prominent lymphoid cuff and lymphoid infiltration were destroyed by a laser using the manufacturer's recommendation. Enriched tumor samples were collected from the slides. DNA was extracted as previously described (Lasota et al, 1996).

\section{LOH Studies Based on PCR-Amplified Microsatellite Markers}

All chromosome 17 and 22 polymorphic markers used in this study are listed in Figure 3. Primer sequences for microsatellite markers were obtained from previously published studies (Eisenbarth et al, 2000) and from the genetic databases available online through the National Center for Biotechnology Information (NCBI) (http://www.ncbi.nlm.nih.gov). PCR amplification of microsatellite markers was performed as previously described (Lasota et al, 2001). The PCR products were analyzed using ABI PRISM 310 and GENESCAN software (PE Applied Biosystems, Foster City, California). LOH was defined mathematically as recommended by PE Applied Biosystems. Although $\mathrm{LOH}$ values $\leq 0.5$ and $\geq 1.5$ indicate significant loss of one allele (PE Applied Biosystems Manual) and are often used in the literature, we performed a pilot study to verify these values in the context of our laboratory. Twenty meningiomas that are often characterized by frequent losses of chromosome 22 were evaluated as 
controls. In 13 cases, $\mathrm{LOH}$ values for all analyzed microsatellite markers were $\leq 0.5$ and $\geq 1.5$, indicating loss of one copy of chromosome $22 \mathrm{q}$.

Additional NF2 and NF1 intragenic polymorphic markers were evaluated by nested PCR amplification and direct sequencing. Five previously described (Legoix et al, 1999) NF2 markers were based on single nucleotide polymorphism or repeat polymorphism in the promoter region [8240G/C, 8348(T)6-7], intron 13 [80289(CA)3-4], and the $3^{\prime}$ region $[99632 \mathrm{C} / \mathrm{T}$, 106768(GA)7-8] of the gene. Also, a new single nucleotide polymorphism, G/A at nucleotide position 8210 , was identified and evaluated. Primers were designed based on NF2 sequences available at the GenBank database under accession number Y18000. Location of the primers and annealing temperatures are listed in the Table 2. Rsal polymorphism in exon 5 of NF1 (Hoffmeyer and Assum, 1994) was amplified by nested PCR. Primers were designed based on NF1 sequences available at the GenBank database under accession number U17662. PCR consisted of 20 cycles with forward primer, nf1.5.1f (5'ACATGTGGTTCTITATTTATAG $\left.3^{\prime}\right)$, and reverse primer, nf1.5.2R (5' TCAATCGTATCCTTAC 3'), followed by 30 cycles with the same forward and nested reverse primer, nf1.5.3R (5'CGTATCCTTACCAGCCAT3'). PCR conditions were standard as recommended by Perkin-Elmer (Norwalk, Connecticut), with an annealing temperature of $55^{\circ} \mathrm{C}$.

Table 2. PCRs Used to Amplify NF2 Coding Sequences and Polymorphic Markers

\begin{tabular}{|c|c|c|c|c|}
\hline $\begin{array}{l}\text { Forward primer } \\
\quad(\text { position })^{a}\end{array}$ & $\begin{array}{l}\text { Reverse primer } \\
\quad(\text { position })^{a}\end{array}$ & PCR & $\begin{array}{l}\text { Annealing } \\
\text { temperature }\end{array}$ & $\begin{array}{c}\text { Target of } \\
\text { amplification }\end{array}$ \\
\hline$F 1^{8420}(8146-65)$ & $\mathrm{R} 3^{8420}(8263-82)$ & First & $60^{\circ} \mathrm{C}$ & \\
\hline$F 2^{8420}(8161-80)$ & $\mathrm{R} 3^{8240}$ & Nested & $60^{\circ} \mathrm{C}$ & $8210 \mathrm{G} / \mathrm{A} ; 8240 \mathrm{G} / \mathrm{C}$ \\
\hline$F 1^{8348}(8301-20)$ & $\mathrm{R} 2^{8348}(8425-46)$ & First & $55^{\circ} \mathrm{C}$ & \\
\hline $\mathrm{F} 1^{8348}$ & $\mathrm{R} 3^{8348}(8411-30)$ & Nested & $60^{\circ} \mathrm{C}$ & $8348(T) 6-7$ \\
\hline E1F3 (8906-25) & E1R4 (9179-99) & First & $55^{\circ} \mathrm{C}$ & \\
\hline E1F3 & E1R2 (9135-54) & Nested & $55^{\circ} \mathrm{C}$ & NF2 Exon 1 \\
\hline E2F1 (41161-80) & E2R2 (41449-70) & First & $55^{\circ} \mathrm{C}$ & \\
\hline E2F2 (41200-23) & $\mathrm{E} 2 \mathrm{R} 2$ & Nested & $55^{\circ} \mathrm{C}$ & NF2 Exon 2 \\
\hline E3F1 (43520-41) & E3R1 (43721-40) & First & $50^{\circ} \mathrm{C}$ & \\
\hline E3F1 & E3R2 (43701-20) & Nested & $55^{\circ} \mathrm{C}$ & NF2 Exon 3 \\
\hline E4F2 (46622-41) & E4R1 (46811-46830) & First & $55^{\circ} \mathrm{C}$ & \\
\hline E4F1 (46661-80) & E4R1 & Nested & $55^{\circ} \mathrm{C}$ & NF2 Exon 4 \\
\hline E5F0 (59081-100) & E5R1 (59233-56) & First & $55^{\circ} \mathrm{C}$ & \\
\hline E5F1 (59106-25) & $\mathrm{E} 5 \mathrm{R} 1$ & Nested & $55^{\circ} \mathrm{C}$ & NF2 Exon 5 \\
\hline E6F0 (59861-80) & E6R1 & First & $50^{\circ} \mathrm{C}$ & \\
\hline E6F1 (59944-63) & E6R1 (60166-85) & Nested & $50^{\circ} \mathrm{C}$ & NF2 Exon 6 \\
\hline E7F0 & E7R1 (62761-80) & First & $50^{\circ} \mathrm{C}$ & \\
\hline E7F1 (62641-60) & E7R1 & Nested & $50^{\circ} \mathrm{C}$ & NF2 Exon 7 \\
\hline E8F1 (65571-90) & E8R1 (65831-50) & First & $55^{\circ} \mathrm{C}$ & \\
\hline E8F2 (65591-600) & E8R1 & Nested & $55^{\circ} \mathrm{C}$ & NF2 Exon 8 \\
\hline E9F2 (69421-40) & E9R2 (69554-71) & First & $45^{\circ} \mathrm{C}$ & \\
\hline E9F3 (69450-67) & E9R2 & Nested & $45^{\circ} \mathrm{C}$ & NF2 Exon 9 \\
\hline E10F2 (72788-804) & E10R1 (72951-70) & First & $55^{\circ} \mathrm{C}$ & \\
\hline E10F2 & E10R2 (72935-52) & Nested & $45^{\circ} \mathrm{C}$ & NF2 Exon 10 \\
\hline E11F2 (76210-29) & E11R2 (76441-64) & First & $55^{\circ} \mathrm{C}$ & \\
\hline $\mathrm{E} 11 \mathrm{~F} 2$ & E11R1 (76410-29) & Nested & $55^{\circ} \mathrm{C}$ & NF2 Exon 11 \\
\hline E12F1 (77712-31) & E12R3 (78030-59) & First & $50^{\circ} \mathrm{C}$ & \\
\hline $\mathrm{E} 12 \mathrm{~F} 1$ & E12R2 (77975-94) & Nested & $55^{\circ} \mathrm{C}$ & NF2 Exon 12 \\
\hline E13F0 (79261-80) & E13R1 (79441-60) & First & $55^{\circ} \mathrm{C}$ & \\
\hline E13F1 (79281-300) & E13R1 & Nested & $55^{\circ} \mathrm{C}$ & NF2 Exon 13 \\
\hline $\mathrm{F}^{80289}(80121-40)$ & $R 6^{80289}(80361-80)$ & First & $55^{\circ} \mathrm{C}$ & \\
\hline $\mathrm{F} 5^{80289}$ & $\mathrm{R} 7^{80289}(80341-60)$ & Nested & $60^{\circ} \mathrm{C}$ & $80289(\mathrm{CA}) 3-4$ \\
\hline E14F1 (82621-40) & E14R1 (82837-56) & First & $55^{\circ} \mathrm{C}$ & \\
\hline E14F2 (82641-60) & E14R1 & Nested & $55^{\circ} \mathrm{C}$ & NF2 Exon 14 \\
\hline E15F1 (85861-80) & E15R2 (86131-50) & First & $55^{\circ} \mathrm{C}$ & \\
\hline E15F1 & E15R1 (86108-27) & Nested & $55^{\circ} \mathrm{C}$ & NF2 Exon 15 \\
\hline F3 ${ }^{99632}(99481-500)$ & $\mathrm{R} 4^{99632}(99691-710)$ & First & $55^{\circ} \mathrm{C}$ & \\
\hline $\mathrm{F}^{99632}$ & R3 ${ }^{99632}(99660-79)$ & Nested & $55^{\circ} \mathrm{C}$ & 99632C/T \\
\hline$F 1^{106768}(106684-703)$ & $\mathrm{R} 2^{106768}(106875-94)$ & First & $60^{\circ} \mathrm{C}$ & \\
\hline $\mathrm{F} 1^{106768}$ & $\mathrm{R}^{106768}(106851-70)$ & Nested & $60^{\circ} \mathrm{C}$ & 106768(GA)7-8 \\
\hline
\end{tabular}

${ }^{a}$ Numbers refers to the NF2 sequences available at GenBank database (accession number Y18000).

$E$, exon; $F$, forward; $R$, reverse. 
All PCR products were size fractionated on $2.5 \%$ agarose gels, purified from the gels (Qiagene Inc., Chatsworth, California), and sequenced directly on a 373 DNA-sequencer (PE Applied Biosystems) using forward and reverse primers. Computer analysis of the DNA sequences was performed using the Lasergene software (DNASTAR, Madison, Wisconsin). In all PCR experiments, previously described precautions were undertaken to prevent PCR contamination (Lasota et al, 1998).

\section{Search for the Somatic NF2 Mutations}

The coding sequences of NF2 (exons 1-15) were PCR amplified, sequenced directly, and screened for the mutations as previously described (Lasota et al, 2001). In selected cases with severe DNA degradation, nested reactions were performed. Primer positions and annealing temperatures are shown in Table 2. Positive control of PCR amplification and direct sequencing consist of meningiomas analyzed simultaneously with Gl schwannomas. Nine NF2 mutations were found in the 20 meningiomas.

\section{Acknowledgements}

We thank the technicians Ms. Virginia Achstetter and Ms. Wanda King for skillful assistance.

\section{References}

Bijlsma EK, Merel P, Bosch DA, Westerveld A, Delattre O, Thomas G, and Hulsebos TJM (1994). Analysis of mutations in the $\mathrm{SCH}$ gene in schwannomas. Genes Chromosomes Cancer 11:7-14.

Boddrich A, Robinson PN, Schulke M, Buske A, Tinschert S, and Nürnberg $P$ (1997). New evidence for a mutation hotspot in exon 37 of the NF1 gene. Hum Mutat 9:374-377.

Bruder CE, Ichimura K, Tingby O, Hirakawa K, Komatsuzaki A, Tamura A, Yuasa Y, Collins VP, and Dumanski JP (1999). A group of schwannomas with interstitial deletions on $22 q$ located outside the NF2 locus shows no detectable mutations in the NF2 gene. Hum Genet 104:418-424.

Cawthon RM, Weiss R, Xu GF, Viskochil D, Culver M, Stevens J, Robertson M, Dunn D, Gesteland R, O'Connell P, and White $R$ (1990). A major segment of the neurofibromatosis type 1 gene: cDNA sequence, genomic structure, and point mutations. Cell 62:193-201.

Cichowski K and Jacks T (2001). NF1 tumor suppressor gene function: Narrowing the GAP. Cell 104:593-604.

Colman SD, Williams CA, and Wallace RW (1995). Benign neurofibromas in type 1 neurofibromatosis (NF1) show somatic deletions of the NF1 gene. Nat Genet 11:90-92.

Daimaru Y, Kido H, Hashimoto H, and Enjoji M (1988). Benign schwannoma of the gastrointestinal tract: A clinicopathologic and immunohistochemical study. Hum Pathol 19:257-264.

Däschner K, Assum G, Eisenbarth I, Krone W, Hoffmeyer S, Wortmann S, Heymer B, and Keher-Sawatzki H (1997). Clonal origin of tumor cells in a plexiform neurofibroma with LOH in NF1 intron 38 and in dermal neurofibromas without $\mathrm{LOH}$ of the NF1 gene. Biochem Biophys Res Commun 234:346-350.
Eisenbarth I, Beyer K, Krone W, and Assum G (2000). Toward a survey of somatic mutation of the NF1 gene in benign neurofibromas of patients with neurofibromatosis type 1 . Am J Hum Genet 66:393-401.

Gutmann DH (1997). Molecular insights into neurofibromatosis 2. Neurobiol Dis 3:247-261.

Gutmann DH, Giordano MJ, Fishback AS, and Guha A (1997). Loss of merlin expression in sporadic meningiomas, ependymomas and schwannomas. Neurology 49:267-270.

Gutzmer R, Herbst RA, Mommert S, Kiehl P, Matiaske F, Rütten A, Kapp A, and Weiss J (2000). Allelic loss at the neurofibromatosis type 1 (NF1) gene locus is frequent in desmoplastic neurotropic melanoma. Hum Genet 107:357361.

Heim S and Mitelman F (1995). Tumors of the nervous system. In: Cancer cytogenetics. New York: Wiley-Liss, 446447.

Hirose T, Scheithauer BW, and Sanot T (1997). Giant plexiform schwannoma: A report of two cases with soft tissue and visceral involvement. Mod Pathol 10:1075-1081.

Hoffmeyer S and Assum G (1994). An Rsal polymorphism in the transcribed region of the neurofibromatosis (NF1)-gene. Hum Genet 93:481-482.

Hovens CM and Kaye AH (2001). The tumour suppressor protein NF2/merlin: The puzzle continues. J Clin Neurosci $8: 4-7$.

Jacoby LB, MacCollin M, Barone R, Ramesh V, and Gusella JF (1996). Frequency and distribution of NF2 mutations in schwannomas. Genes Chromosomes Cancer 17:45-55.

John AM, Ruggieri M, Ferner R, and Upadhyaya M (2000). A search for evidence of somatic mutations in the NF1 gene. J Med Genet 37:44-49.

Kimura Y, Koga H, Araki N, Mugita N, Fujita N, Takeshima H, Nishi T, Yamashima T, Saido TC, Yamasaki T, Moritake K, Saya H, and Nakao M (1998). The involvement of calpaindependent proteolysis of the tumor suppressor NF2 (merlin) in schwannomas and meningiomas. Nat Med 4:915-922.

Kluwe L, Friedrich RE, and Mautner VF (1999). Allelic loss of the NF1 gene in NF1-associated plexiform neurofibromas. Cancer Genet Cytogenet 113:65-69.

Kluwe L, Hagel C, Tatagiba M, Thomas S, Stavrou D, Ostertag H, von Deimling A, and Mautner VF (2001). Loss of NF1 alleles distinguish sporadic from NF1-associated pilocytic astrocytomas. J Neuropathol Exp Neurol 60:917-920.

Knudson AG (1971). Mutation and cancer: Statistical study of retinoblastoma. Proc Natl Acad Sci USA 68:820-823.

Koga $\mathrm{T}$, Iwasaki $\mathrm{H}$, Ishiguro $\mathrm{M}$, Matsuzaki $\mathrm{A}$, and Kikuchi $\mathrm{M}$ (2002). Frequent genomic imbalances in chromosomes 17 , 19 and $22 q$ in peripheral nerve sheath tumours detected by comparative genomic hybridization analysis. J Pathol 197: 98-107.

Lasota J, Fetsch JF, Wozniak A, Wasag B, Sciot R, and Miettinen M (2001). The neurofibromatosis type 2 (NF2) gene is mutated in perineurial cell tumors: A molecular genetic study of 8 cases. Am J Pathol 158:1223-1229.

Lasota J, Franssila K, Koo CH, and Miettinen M (1996). Molecular diagnosis of mantle cell lymphoma in paraffinembedded tissue. Mod Pathol 9:361-366. 
Lasota J, Jasinski M, Debiec-Rychter M, Szadowska A, Limon J, and Miettinen M (1998). Detection of the SYT-SSX fusion transcripts in formaldehyde-fixed, paraffin-embedded tissue: A reverse transcription polymerase chain reaction amplification assay useful in the diagnosis of synovial sarcoma. Mod Pathol 11:626-633.

Legoix P, Legrand M-F, Ollagnon E, Lenoir G, Thomas G, and Zuckman-Rossi J (1999). Characterisation of 16 polymorphic markers in the NF2 gene: Application to hemizygosity detection. Hum Mutat 13:290-293.

Li Y, O'Connell P, Breidenbach HH, Cawthon R, Stevens J, Xu G, Neil S, Robertson M, White R, and Viskochil D (1995). Genomic organization of the neurofibromatosis 1 gene (NF1). Genomics 25:9-18.

Lothe RA, Slettan A, Saeter G, Brøgger A, Børresen A-L, and Nesland JM (1995). Alterations at chromosome 17 loci in peripheral nerve sheath tumors. J Neuropathol Exp Neurol 54:65-73.

Merel P, Khe HX, Sanson M, Bijlsma E, Rouleau G, LaurentPuig P, Pulst S, Baser M, Lenoir G, and Sterkers JM (1995). Screening for germ-line mutations in the NF2 gene. Genes Chromosomes Cancer 12:117-127.

McCormick F (1995). Ras signaling and NF1. Curr Opin Genet Dev 5:51-55.

Mertens F, Dal Cin P, De Wever I, Fletcher CDM, Mandahl N, Mitelman F, Rosai J, Rydholm A, Sciot R, Tallini G, van den Berghe H, Vanni R, and Willén H (2000). Cytogenetic characterization of peripheral nerve sheath tumorous: A report of the CHAMP study group. J Pathol 190:31-38.

Messiaen L, Callens T, De Paepe A, Craen M, and Mortier G (1997). Characterisation of two different nonsense mutations C6792A and C6792G, causing skipping of exon 37 in the NF1 gene. Hum Genet 101:75-80.

Miettinen M, Shekitka KM, and Sobin LH (2001). Schwannomas in the colon and rectum: A clinicopathologic and immunohistochemical study of twenty cases. Am J Surg Pathol 25:846-855.

Mitelman F (1998). Catalog of chromosome aberrations in cancer, 6th ed. New York: Wiley-Liss.

Perry A, Roth KA, Banerjee R, Fuller CE, and Gutmann DH (2001). NF1 deletions in S-100 protein-positive and negative cells of sporadic and neurofibromatosis 1 (NF1)-associated plexiform neurofibromas and malignant peripheral nerve sheath tumors. Am J Pathol 159:57-61.

Prévot S, Bienvenu L, Vaillant JC, and de Saint-Maur PP (1999). Benign schwannoma of the digestive tract: A clinicopathologic and immunohistochemical study of five cases, including a case of esophageal tumor. Am J Surg Pathol 23:431-436.

Rasmussen SA and Friedman JM (2000). NF1 gene and neurofibromatosis 1. Am J Epidemiol 151:33-40.

Rasmussen SA, Overman J, Thomson SAM, Colman SD, Abernathy CR, Trimpert RE, Moose R, Virdi G, Roux K, Bauer M, Rojiani AM, Maria BL, Muir D, and Wallace MR (2000). Chromosome 17 loss-of-heterozygosity studies in benign and malignant tumors in neurofibromatosis type I. Genes Chromosomes Cancer 28:425-431.

Robinson PN, Boddrich A, Peters H, Tinschert S, Buske A, Kaufmann D, and Nürnberg $P$ (1995). Two current nonsense mutations and a $4 \mathrm{bp}$ deletion in a quasi-symmetric element in exon 37 of the NF1 gene. Hum Genet 96:95-98.
Rouleau GA, Merel P, Lutchman M, Sanson M, Zucman J, Marineau C, Hoang-Xuan K, Demczuk S, Desmaze C, Plougastel B, Pulst SM, Lenoir G, Bijlsma E, Fashold R, Dumanski J, de Jong $P$, Parry D, Eldrige R, Aurias A, Delattre $O$, and Thomas $G$ (1993). Alteration in a new gene encoding a putative membrane-organizing protein causes neurofibromatosis type 2. Nature 363:515-521.

Ruttledge MH, Andermann AA, Phelan CM, Claudio JO, Han FY, Chretien N, Rangaratnam S, MacCollin M, Short P, Parry D, Michels V, Riccardi VM, Weksberg R, Kitamura K, Bradburn JM, Hall BD, Propping P, and Rouleau GA (1996). Type of mutation in the neurofibromatosis type 2 gene (NF2) frequently determines severity of disease. Am J Hum Genet 59:331-342.

Sarlomo-Rikala M and Miettinen M (1995). Gastric schwannoma: Clinicopathological analysis of six cases. Histopathology 27:335-340.

Sasatomi T, Tsuji Y, Tanaka S, Horiuchi H, Hyodo S, Takeuchi K, Nakashima O, and Shirouzu K (2000). Schwannoma of the sigmoid colon: Report of a case. Kurume Med J 47:165168.

Scheithauer BW, Woodruff JM, and Erlandson RA (1999). Tumors of the peripheral nervous system. In: Rosai J, editor. Atlas of tumor pathology. Washington, DC: Armed Forces Institute of Pathology, 105-176.

Serra E, Puig S, Otero D, Gaona A, Kruyer H, Ars E, Estivill X, and Lázaro C (1997). Conformation of a double-hit model for the NF1 gene in benign neurofibromas. Am J Hum Genet 61:512-519.

Serra E, Rosenbaum T, Winner U, Aledo R, Ars E, Estivill X, Lenard H, and Lazaro C (2000). Schwann cells harbor the somatic NF1 mutation in neurofibromas: Evidence of two different Schwann cell populations. Hum Mol Genet 9:30553064.

Skopelitou AS, Mylonakis EP, Charchanti AV, and Kappas AM (1998). Cellular neurilemoma (schwannoma) of the descending colon mimicking carcinoma: Report of a case. Dis Colon Rectum 41:1193-1196.

Skuse GR, Kosciolek BA, and Rowley PT (1989). Molecular genetic analysis of tumors in von Recklinghausen neurofibromatosis: Loss of heterozygosity for chromosome 17. Genes Chromosomes Cancer 1:36-41.

Stemmer-Rachamimov AO, Xu L, Gonzalez-Agosti C, Burwick JA, Pinney D, Beauchamp R, Jacoby LB, Gusella JF, Ramesh V, and Louis DN (1997). Universal absence of merlin, but not other ERM family members, in schwannomas. Am J Pathol 151:1649-1654.

Tomozawa S, Masaki T, Matsuda K, Yokoyama T, Ishida T, and Muto T (1998). A schwannoma of the cecum: Case report and review of Japanese schwannomas in the large intestine. J Gastroenterol 33:872-875.

Toliat MR, Erdogan F, Gewies A, Fahsold R, Buske A, Tinschert S, and Nurnberg P (2000). Analysis of the NF1 gene by temperature gradient gel electrophoresis reveals a high incidence of mutations in exon $4 \mathrm{~b}$. Electrophoresis 21:541544.

Trofatter JA, MacCollin MM, Rutter JL, Murrell JR, Duyao MP, Parry DM, Eldridge R, Kley N, Menon AG, Pulaski K, Haase VH, Ambrose CM, Munroe D, Bove D, Haines JL, Martuza RL, MacDonald ME, Seizinger BR, Short MP, Buckler AJ, and Gusella JF (1993). A novel moesin-, ezrin-, 
radixin-like gene is a candidate for the neurofibromatosis 2 tumor suppressor. Cell 72:791-800.

Twist EC, Ruttledge MH, Rousseau M, Sanson M, Papi M, Merel P, Delattre O, Thomas G, and Rouleau GA (1994). The neurofibromatosis type 2 gene is inactivated in schwannomas. Hum Mol Genet 3:147-151.

Upadhyaya M, Osborn M, Maynard J, and Harper P (1996). Characterization of six mutations in exon 37 of neurofibromatosis type 1 gene. Am J Med Genet 67:421-423.

Wallace MR, Marchuk DA, Anderson LB, Letcher R, Odeh HM, Saulino AM, Fountain JW, Brereton A, Nicholson J, Mitchell AL, Brownstein BH, and Collins FS (1990). Type 1 neurofibromatosis gene: Identification of a large transcript disrupted in three NF1 patients. Science 249:181-186.

Xu G, Lin B, Tanaka K, Dunn D, Wood D, Gesteland R, White $\mathrm{R}$, Weiss R, and Tamanoi F (1990b). The catalytic domain of the neurofibromatosis type 1 gene product stimulates ras GTPase and complements ira mutants of $S$. cerevisiae. Cell 63:835-841.

Xu G, O’Connell P, Viskochil D, Cawthon R, Robertson M, Culver M, Dunn D, Stevens J, Gesteland R, White R, and Weiss R (1990a). The neurofibromatosis type 1 gene encodes a protein related to GAP. Cell 62:599-608.
Yagihashi N, Kaimori M, Katayama Y, and Yagihashi S (1997). Crystalloid formation in gastrointestinal schwannoma. Hum Pathol 28:304-308.

Yunoue S, Tokuo H, Fukunaga K, Feng L, Ozawa T, Nishi T, Kikuchi A, Hattori S, Kuratsu J, Saya H, and Araki N (2003). Neurofibromatosis type I tumor suppressor neurofibromin regulates neuronal differentiation via its GTPase-activating protein function toward Ras. J Biol Chem 278:26958-26969.

Zhu Y, Ghosh P, Charnay P, Burns DK, and Parada LF (2002). Neurofibromas in NF1: Schwann cell origin and role of tumor environment. Science 296:920-922.

Zucman-Rossi J, Legoix P, Der Sarkissian H, Cheret G, Sor F, Bernardi A, Cazes L, Giraud S, Lenoir G, and Thomas G (1998). Exhaustive characterization of the NF2 gene in neurofibromatosis type 2 patients. Hum Mol Genet 7:2095-2101. 